v. $13, n .4$

Vitória-ES, Jul.-Aug. 2016

p. $24-48 \quad$ ISSN 1808-2386 DOI: $h$ ttp://dx.doi.org/10.15728/bbr.2016.13.4.2

\title{
Effect of Victories and Defeats on the Attitude of Soccer Fans: a Study
}

Concerning Pitchman, Involvement and Fanaticism

\author{
Fernando A. Fleury ${ }^{\dagger}$ \\ Nove de Julho University - UNINOVE \\ Vitor Koki da Costa Nogami ${ }^{\Omega}$ \\ José Afonso Mazzon ${ }^{¥}$
University of São Paulo - USP \\ Andres Rodriguez Veloso ${ }^{ \pm}$ \\ University of São Paulo - USP
}

School of Economics, Business and Accounting of the University of São Paulo - FEA-USP

\begin{abstract}
This paper aims to analyze the attitude of soccer fans after the outcome of matches under the influence of a pitchman (celebrities and idols), involvement and fanaticism. The literature was supported by the concepts of happiness and attitude applied to sports, interacting with the literature on the influence of the pitchman (studies 1 and 2), involvement (study 3) and fanaticism (study 4). The data was collected in four rounds of the Brazilian soccer league, comprising 931 fans of the 16 best teams in the country. The data was analyzed using the GLM (General Linear Model). The findings indicate that the outcome of the match will have more influence on the attitude of fans than the endorsement of a pitchman, and that this influence is enhanced by the involvement and fanaticism of fans.
\end{abstract}

Keywords: Pitchman. Involvement. Fanaticism. Fan's attitude. Soccer fan.

Received on 02/05/2015; Reviewed on 05/11/2015;Accepted on 06/01/2015; Divulgued on 07/04/2016.

\footnotetext{
*Author for correspondence:

†. PhD in Business Administration from the University of São Paulo USP.

Link: Professor of the Master in Sport Management (MPA- GE) in Nove de Julho University Uninove.

Address: Avenue Francisco Matarazzo, 612, Prédio C - $2^{\circ}$. São Paulo - SP - Brazil. Cep. 05001-100

E-mail: fleury@uninove.br

$\Omega \mathrm{PhD}$ Student in Business Administration by the School of Economics, Business and Accounting of the University of São Paulo Link:

Address: Avenue Professor Luciano Gualberto, 908, Butantã, São Paulo - SP Brazil. Cep. 05508-010.

E-mail: vitornogami@usp.br
}

\author{
$¥$ Doctor in Administration by \pm Doctor in \\ the University of São Paulo - Administration by the \\ USP. \\ Link: Professor in Business \\ Administration at FEA -USP. \\ Address: Avenue Professor \\ Luciano Gualberto, 908, \\ Butantã, São Paulo - SP - \\ Brazil. Cep. 05508-010. \\ E-mail: jamazzon@usp.br \\ University of São \\ Paulo - USP \\ Link: Full Professor at \\ the University of São \\ Paulo - USP. \\ Address: Avenue \\ Professor Luciano \\ Gualberto, 908, \\ Butantã, São Paulo - \\ SP - Brazil. Cep. \\ 05508-010. \\ E-mail: veloso@usp.br
}




\section{INTRODUCTION}

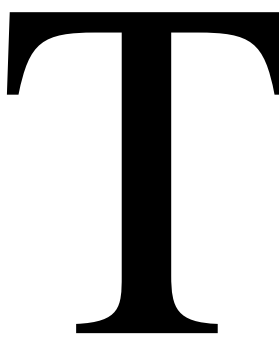

he lack of professionalism of Brazilian sports clubs influences various management problems, such as delayed wages of players, debt, problems with elections, conflicts with the fans and the media, among other aggravating aspects caused by mismanagement (GRAY; WERT-GRAY, 2012). In this context, managing a club as a proper company, with all associated techniques, methods and organizational procedures, becomes critical to the maintenance of the clubs. Under this perspective, we sought to understand soccer fans/consumer behavior from the point of view of marketing management. Therefore, the aim of our paper is to analyze the attitude of soccer fans immediately after the matches, under the influence of the pitchman (celebrities and idols), involvement and fanaticism. In this sense, knowing the behavior and attitudes of consumers contributes to marketing management of the club.

Gray and Wert-Gray (2012) report that the sports industry has been studied internationally in recent decades in its different forms. These studies found that sports consumers consist of several groups that differ in attitudes and behaviors (QUICK, 2000). In Brazil, the study on sports is still at an early stage both in academia and within the clubs. Our study seeks to contribute to understanding the behavior and attitude of the consumer, to offer different marketing actions in situations of victory and defeat. Professional sports team will sometimes win and sometimes loose. This is a fact. In light of these events the teams need to focus on the fans, the "supreme authority" (TAYLOR, 1992, p. 118), in the sport market to expose the fans to more targeted marketing actions (KWAK; KIM; HIRT, 2011). The marketing management team deal with promotion efforts to increase positive attitudes, and therefore, the growth of flow fans in the stadium, increasing TV ratings and the direct or indirect consumer products clubs (TOKAYAMA; GREENWELL, 2011).

Understanding the relationship between fans and sports teams is the subject of international studies long ago. One of the forerunners in this area was the paper of Cialdini et al. (1976), which showed the relation between victories and defeats and the behavior of fans, specifically their behavior regarding attending matches at a stadium. The defeats specifically cause a phenomenon of approximation and repulsion at the same time. Happiness wins provides more fans in the stadium, however, in defeat there are fans who prefer not accompany the team, on the other hand there are the fans who realize the need for support for team. The relation of victory and increased sales of products and the relation of defeat and 
decreased sales of products seems obvious, but the relation between defeat and fans go to the stadium is not so clear. These studies were essential to increase scientific knowledge on the subject (FUNK; JAMES, 2001).

Research studies using celebrities to influence the opinion of consumers and, consequently, their purchase decisions are not new (SHUART, 2007). Using celebrities as pitchman for boosting sales of products and services is an endorsement that directly influences consumer behavior. In addition to the celebrities, athletes appear in their roles as pseudo-heroes (DRUCKER; CATHCART, 1997). Besides the idols of teams soccer players also perform the role of celebrities which combined with their characterization of pseudoheroes can generate an even greater endorsement before consumers/fans of clubs (JONES; SCHUMANN, 2000). Justifying the behavior of fans by cognitive, affective, and emotional aspects has also been object of study (FUNK; JAMES, 2001).

Therefore, merging all these variables using an experimental technique to investigate the moderating influence of pitchman, involvement and fanaticism of fans is an unprecedented contribution that we aim to achieve with this paper. Thus, our research question is: how is the attitude of soccer fans affected by pitchman, involvement and fanaticism moderation immediately after the matches?

For that purpose, we conducted four studies to analyze the attitude of fans following the outcome of matches (victory vs. defeat), and influenced by celebrities, such as a pitchman (study 1), idols as pitchman (study 2), involvement (study 3 ) and fanaticism (study 4).

\section{THEORETICAL BACKGROUND}

In this work, victories and defeats were used as factors for fan's happiness or nonhappiness, because, according to Lewis et al. (2008), situations that appear pleasing to consumers contribute to their good mood and drive them to a positive emotional state (happiness), which may be transferred to their purchasing behavior (LABROO; PATRICK, 2009; GUVEN, 2012; MOGILNER et al., 2012). Similarly, defeat will bring sadness and unpleasant sensations to consumers (MOGILNER et al., 2012; LEWIS et al., 2008), driving them towards non-happiness. The behavioral attitude, which originates from the three dimensions of the attitude construct (AJZEN; FISHBEIN, 1977; BAGOZZI et al, 1979; FISHBEIN; MIDDLESTADT, 1995), establishes the intentions and interests of consumers with regard to something, and are developed, in this paper, through the constructs involvement, which is one's personal connection with the sport (KUNKEL et al, 2013), and fanaticism, consisting of the degree of linkage between the fan and his team (GWINNER; 
SWANSON, 2003).

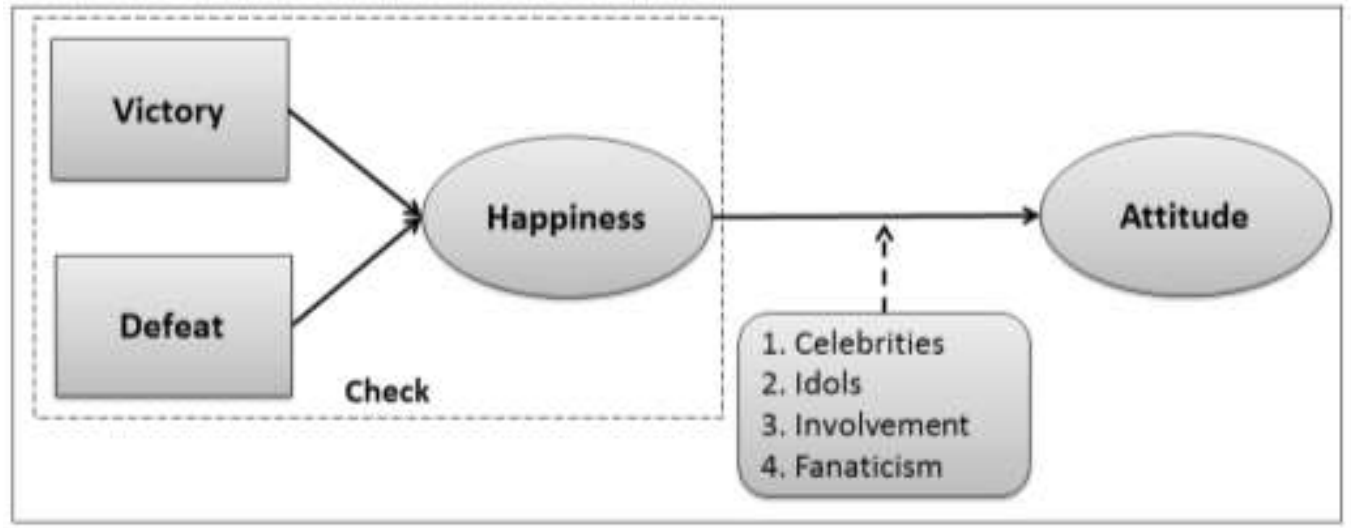

Figure 1 - Theoretical model

Source: Elaborated by the authors.

Figure 1 illustrates our theoretical proposition for the 4 studies. Considering that the happiness of fans is influenced by their team's victory or defeat, and that happiness influences the attitude of fans, the proposed theoretical model analyzes this relationship with the moderating effect of celebrities (study 1), idols (study 2), involvement (study 3) and fanaticism (study 4).

\subsection{HAPPINESS}

Under normal purchasing conditions, we assume that a positive mood (good mood), reflecting a pleasant environment and a combination of good sensations that cause happiness, is a pleasant situation for people (LEWIS et al., 2008). On the other hand, a negative mood (bad mood), reflecting an uncomfortable environment and a combination of bad sensations that cause sadness (or non-happiness), is an unpleasant situation for people (MOGILNER et al. 2012; Lewis et al., 2008). In other words, there is a combination of factors that makes people more or less happy (GRAY; WATSON, 2007). These factors may be intrinsic or extrinsic to the human being (LAYARD, 2005).

Once a person is in a positive emotional state, i.e., if one is happy, this can be transferred to their behaviors; in this particular case, buying behavior (LABROO; PATRICK, 2009; GUVEN, 2012; MOGILNER et al., 2012). Excitement, good mood and positive emotional circumstances involve people and stimulate shopping, which perhaps would not occur in situations not as engaging or joyful (LAYARD, 2005). Common sense, combined with some scientific studies, suggest that the emotional state of non-happiness also stimulates consumption (GRAY; WATSON, 2007; GUVEN, 2012). Stress, suffering, nervousness, anxiety, and other negative feelings, make people try to regulate emotion through purchasing. Emotions are rather present in sports environments, related to players and coaching staff, or 
journalists, media and fans. Specifically in Brazil, soccer has a prominent position in the behavior and emotion relationship among fans, who are also consumers of products tied to their clubs.

Within a short-term perspective, the outcome of each game, throughout the rounds of a championship, will change the mood of fans. A victory situation provides a positive emotional state of happiness that can further orient fans/consumers towards purchasing products related to their teams (PHAM, 2007). A defeat situation that may cause a feeling of sadness interferes with this emotional relationship and can lower the intention of fans/consumers towards buying products related to their teams (MOGILNER et al., 2012).

Furthermore, we can also mention the moderation of the expectation for the game results. When fans initially have a high expectation, a draw outcome may produce a defeat feeling and diminish happiness; on the other hand, when expectation is low, a draw outcome may produce feelings of happiness. Whether the game is at home or not, the team has all its starting players or not, or it is well positioned in the standings or not are just some of the several moderating variables that may also influence the emotions after a game result.

It is possible to find several studies on consumption as a way to pursue happiness, i.e., behavior is antecedent and emotion is consequent (LEWIS et al., 2008). This paper aligns the work of other researchers investigating the inverse relation, that is, the emotional state of happiness or non-happiness is antecedent, and purchase intention is consequent (PHAM, 2007; GUVEN, 2012). This bidirectional relationship establishing that which is an antecedent and what is consequence is rather delicate, being influenced by various situations that can moderate and mediate the behavioral and mental structure of consumers (LAYARD, 2005). Therefore, for this research, the emotional state of happiness (high vs. low) that arises from the result of a soccer game influences the attitude of fans/consumers.

\subsection{ATTITUDE}

In general, attitude is measured by assessments on an object which can be favorable or unfavorable, with varying levels of intensity and characteristics (AZJEN, 2001; ALBARRACÍN; JOHNSON; ZANNA, 2005). In the literature about attitudes, it is common to outline the construct into three dimensions: cognitive, affective and behavioral (AJZEN; FISHBEIN, 1977; BAGOZZI et al., 1979; FISHBEIN; MIDDLESTADT, 1995). The cognitive dimension is the individual's information about an object, awareness of the existence of said object, beliefs about the characteristics of the object and judgments about the relative importance of each of these attributes (MILLAR; MILLAR, 1990). In turn, the 
affective dimension is related to the feelings one has towards an object, which can be positive, negative or neutral (ZHAO et al., 2011). The conative or behavioral dimension is related to propensities, interests, intentions and predispositions that one has about an object, in other words, when it comes to the buying behavior, it is the intensity of will and probability of acquiring a product or service (AZJEN; FISHBEIN, 1977; BAGOZZI, 1981). Therefore, we will use the conative attitude dimension in this study, as it is a latent variable closest to the actual consumer behavior.

Several studies show the success of teams on the field as one of the key factors for teams to be successful with fans (LEMKE et al., 2010). This success, which leads to the happiness of fans, can be analyzed in the long-term (good results in championships) or short term (winning a game), so the results of the team on the field will influence the attitude of fans when deciding to consume products related to their team. On the other hand, the failure or non-happiness caused by defeats or tittle loss will eventually lead to an internal restriction on the part of the fan (KIM; TRAIL, 2010). Thus, one can understand that the sport has certain fan self-motivation characteristics (FUNK et al., 2012) which affect their attitude and which are influenced directly, but not solely, by the success or failure of their favorite teams, directly resulting in happiness or non-happiness.

Within this research, specifically regarding the soccer environment, we used the conative attitude as a dependent variable, since the affective relations will be approached as independent variables in the fanaticism and involvement constructs. A fan can express a positive attitude towards his supported team in several ways, from helping to build their home stadium, as in the 50s, to becoming a partner supporter and paying monthly fees to the team. Buying products, going to the stadium, defending the team in social environments and boosting the number of fans are some monetary and non-monetary ways to express positive attitude towards one's team. As a result, the team wins market value, more fans, is able to hire more and better players and pursue victories and titles, consequently increasing the positive attitude of fans it becomes a cycle.

\section{GENERAL METHODS}

Data collection took place in the last four rounds of the 2013 Brazilian Soccer League with fans of the 16 major soccer teams in the country (Appendix A). The survey was always made available in two different times. First, on Saturday, after the last game of the day, until the end of Sunday nights (about 30 hours available, per round). We include only team's fans that the teams played during the Saturday. About the Sunday games we adopted the same 
method, after the last game of the round, until the end of Monday nights (about 30 hours available, per round). We acted as such so that the answers we got from the fans were affected by the emotions of the outcome of match in the round (victory and defeat only, draws were disregarded).

Thus, we conducted four different studies. To select the teams, we evaluated the size of the group of fans, which represent $89.9 \%$ of Brazilian supporters (Pluri, 2013) and total revenues of clubs, which represent $89.6 \%$ of revenues of clubs (BDO, 2013). We provided a link with an invitation, via ESPN's twitter account (@ESPNagora), for fans to respond to the survey. At the end of the last round, we held a drawing for an official shirt chosen by the the wining respondent.

First, the fans answered questions about happiness, in view of the importance of such a feeling in the moment immediately after the outcome of the match (victory vs. defeat), as reviewed previously. By assembling the responses acquired with the four studies, the happiness construct, consisting of 5 items, reached a Cronbach's alpha of .94. The same was performed with the dependent variable attitude, with 7 items, which in this study was based on the conative attitude (AZJEN; FISHBEIN, 1977; BAGOZZI, 1981; FISHBEIN; MIDDLESTADT, 1995), achieving a Cronbach's alpha of .88. Both constructs were present in all four studies.

For each of the rounds, we investigated different concepts that can interact with the outcome of the match, the happiness and attitude of fans: celebrity as pitchman (study 1), idol as pitchman (study 2), involvement (study 3) and fanaticism (study 4). The first two studies are characterized as an experiment, as certain stimuli were manipulated. Each fan received a text with the narration of a pitchman, randomly and always according to the team he supported. The pitchmen were: supporting celebrity or neutral celebrity in study 1 and current or former idol in study 2.

To ensure the effectiveness of the stimulus, the supporting celebrity and the former and current idols were chosen from a poll we conducted at the ESPN website with Internet users. Each participant filled out a brief questionnaire that contained four questions: (a) what is your favorite team?; (b) who is your current team idol; (c) who is your former team idol; and (d) who is the supporting celebrity who identifies well with your team? Participants were asked to name an idol (current and former) and a celebrity in a blank space which better represents the identity of their clubs (Appendix A). 
The excerpt below exemplifies the text read by the respondents:

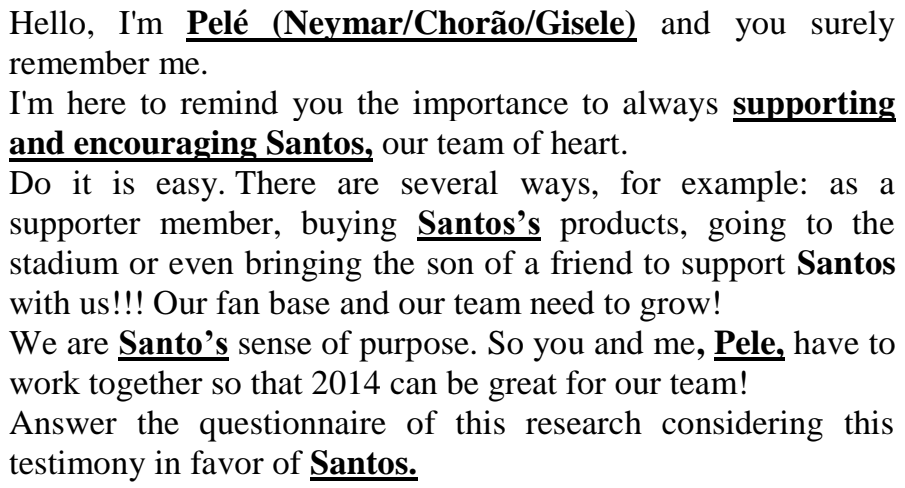

Moreover, in studies 1 and 2, we used images of celebrities (supporting and neutral) and idols (former and new) to endorse the role of the pitchman, images of the team's logo and fans were also used for this purpose. We chose to use an informal language in the text in order to bring the respondent and the pitchman closer together.

Studies 3 and 4 are not characterized as an experiment, as there was no stimuli manipulation, but, in view of the results of studies 1 and 2 , the literature review and the constructed assumptions, the concepts of involvement and fanaticism were analyzed to seek an explanation for the attitude of the fans within the match results and happiness research scenario. As they are similar but different concepts, a factor analysis was also performed between these two constructs. The involvement factor consisting of four items achieved a Cronbach's alpha of .75; the fanaticism factor, also consisting of four items, achieved a Cronbach's alpha of .75 as well. In general, the involvement construct sought to evaluate the frequency with which the supporter follows the sports news on his team and talks about his team with friends. On the other hand, the fanaticism construct was a scale adapted from Gwinner and Swanson (2003), who measured the degree of fanaticism of fans, featuring an even more intense relationship with the team. In all four studies, we used the GLM (General Linear Model) to analyze the results. You can find the Exploratory Factor Analysis (EFA), Cronbach's alpha and the questionnaire in the Appendix B

\subsection{STUDY 1 - CELEBRITY AS PITCHMAN}

The theoretical framework supporting this study indicates that celebrities are people recognized by the public and who use this recognition on behalf of a consumer good. It involves everything from movie and television stars and sports, politics and other personalities (MCCRACKEN, 1989). The use of celebrities by advertisers is a fairly common practice in advertising campaigns aimed at increasing the effectiveness of advertising to convince the consumer and product choice (CHEN et al., 2013). Shimp (2000) had already 
indicated that $25 \%$ of American advertisements used celebrities to endorse their products. One possible explanation for the effectiveness of celebrity endorsements is that consumers tend to believe that great stars have a real affection for the products they represent (SILVERA; AUSTAD, 2004).

The positive effects of celebrity endorsement of products have been previously studied. Sternthal, Phillips and Dholakia (1978) estimate that brands and products that used celebrity endorsement aligned with their products and brands achieved better status. However, we emphasize that every celebrity is unique and has his or her own image (CHOI; RIFON, 2007). Thus, a celebrity can be quite assertive for a product and a total mistake for another, as his or her image is transcended to the particular product or company (MCCRACKEN, 1989).

Brazilian soccer fans have a strong connection to their clubs and the more they are present in the stadiums, the greater the average annual expenditure on their favorite team (FLEURY et al., 2014). Celebrities may influence the choices of consumers and this influence can increase whether the celebrity has a connection with the endorsed product or not, especially when associated with high happiness, which is reflected by the outcome of the game. Therefore, associating the image of the club with a celebrity who already has emotional attachment to the team is a greater endorsement than another celebrity's, hence:

\section{H1: Celebrities known as supporters play stronger influential role than neutral} celebrities, both in victory and defeat.

\subsubsection{Method}

The sample of study 1 consisted of 214 fans gathered after the 35th round of the 2013 Brazilian Championship. Then, we tried to analyze the attitude towards the club with regard to the celebrity effect (neutral vs. supporter) with the outcome of the match (victory vs. defeat). Participants were asked to read a testimonial of celebrities in favor of their teams. Photos of celebrities were used to endorse their images to the fan, having an attachment to the team or not. Fashion model Gisele Bundchen was the chosen neutral celebrity, because she was the celebrity who most appeared as advertising girl and has no emotional attachment to any Brazilian soccer team.

\subsubsection{Results}

Before analyzing the results of the experiment itself, we checked the relation of the outcome of matches with the level of happiness of the fans. The results were positive, that is, fans of teams that have won this round were much happier $\left(\mathrm{HAP}_{\mathrm{vic}}=7.39\right)$ than those who 
supported the teams who had lost $\left(\mathrm{HAP}_{\mathrm{def}}=3.78 ; \mathrm{F}(1.213)=104.632, \mathrm{p}<.000\right)$. By considering the studies on consumption and happiness, we concluded that fans of teams that have won the game, after the match, are more inclined to purchase products and services of the club (LABROO; PATRICK, 2009; MOGILNER et al., 2012).

With regard to the results for the stimuli, the analysis of variance showed a nonsignificant interaction between pitchman and match outcome $(\mathrm{F}(1,213)=.072, \mathrm{p}=.789)$. The fans, in both victory and defeat, have not had their attitude changed significantly by the pitchman $(\mathrm{F}(1.213)=.002, \mathrm{p}=.969)$. Regarding the concept of happiness, represented by match outcome (victory and defeat), the result shows an important index in the attitude of fans $(\mathrm{F}(1.213)=6.543, \mathrm{p}=.011)$, confirming the initial checking.

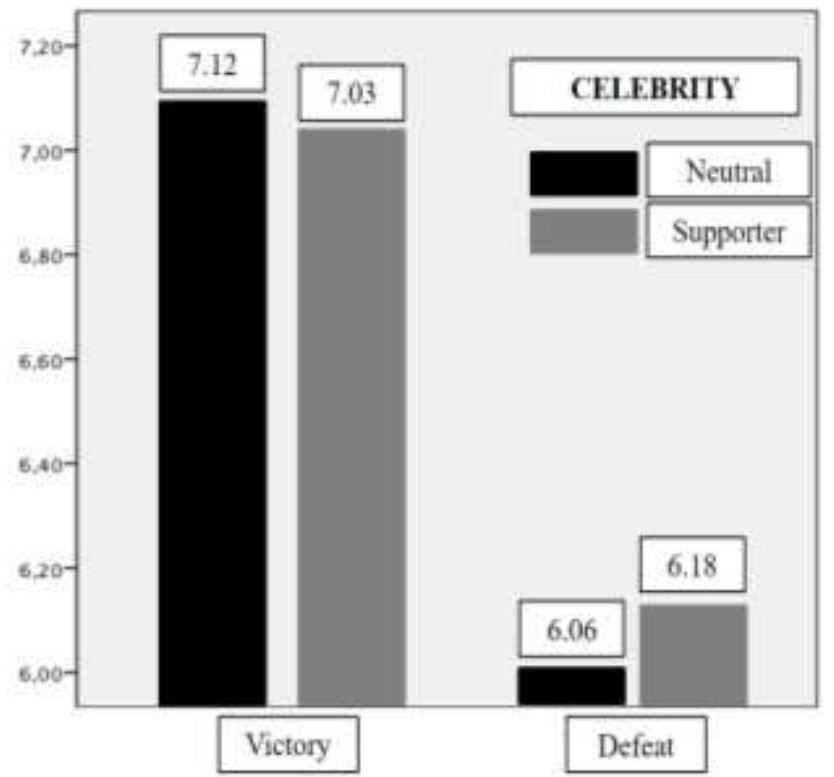

Figure 2 - Effect of the celebrity as a pitchman and the outcome of the match on the attitude of fans Source: Survey data.

The analysis of the results shows that both the neutral celebrity (Gisele Bundchen) and the supporting celebrity will not impact significantly on changing the attitude of fans. Despite being a common practice in advertising campaigns (CHEN et al., 2013), the use of pitchmen after the match to increase the conative attitude of fans towards the club has not proved to be efficient. Thus the result of the game itself has proved to be most influential in the immediate response of fans, that is, intensifying actions to increase the attitude of fans after a victory tends to show efficiency due to the result of the game rather than to the choice, whether right or not, of a pitchman (MCCRACKEN, 1989).

Thus, based on the results, we concluded that the hypothesis 1 of the study was not confirmed. Celebrities, both neutral and supporters, will not influence the attitude of fans after 
a match. Happiness or non-happiness, as a result of victory or defeat, have proved to more likely affect attitude. Therefore, we changed the stimuli for study 2 . The variable independent of match result, which guides happiness, was maintained; in turn, the stimulus was changed from pitchman to team idols, hoping these individuals would exert greater influence on the attitude of fans as they have a stronger bond with the team and the fans.

\subsection{STUDY 2 - IDOLS AS PITCHMEN}

Given that both neutral and supporting celebrities have not influenced the attitude of fans towards their teams, study 2 theoretically proposes the use of team idols as a form of endorsement. Friedman and Friedman (1979) have pointed athletes as sports figures and therefore as celebrities. The same authors highlight three types of endorsers: the celebrity, the professional (or specialist) and the common consumer. The professionals or specialists are those who individually or collectively have great knowledge about the brand or product. In many cases, there is a different kind of celebrity and specialist which is the union of both, that is, when the celebrity also fits the role of professional by endorsing a product or brand (MCCRACKEN, 1989).

In this sense of specialist-celebrity, sports emerge with a huge range of pitchmen, representing up to $60 \%$ of the ads that feature celebrities (CARLSON; DONAVAN, 2008). In many cases, for club fans these athletes go beyond the celebrity status, assuming the role of protagonist in the sporting spectacle. This is the one we call an idol. The image of these celebrities is associated with the importance of the accomplishments that occur throughout the time and space in which their stories are built (MORATO et al., 2011). The sports celebrity, unlike other idols, in many instances is transformed into a hero, which differs from the celebrity as he or she acts to redeem society while celebrities usually live for themselves (HELAL, 2003).

The combination of this three-dimensional facet built by athletes (specialist-celebrity, idol and hero) makes them emerge, especially in the role of pitchmen for products related to their sport and, especially, to their club. However, the construction of an idol is marked by his achievements throughout his time in the team. Thus, sports allow the construction of former idols, who built their stories over time with victories, won championships and overcoming moments; and current idols, who are still working for the team, are already a reference to the team and the crowd and can effectively provide moments of victories and win championships. On the other hand, they can also provide disappointment with defeats or be transfered to a rival team, while all accomplishments of the former idol have already been stored in the 
memory of fans. Therefore, former idols are expected to have more influence on the attitudes of fans as compared to current idols, therefore:

H2: Former idols play a stronger influential role than current idols, both in victory and defeat.

\subsubsection{Method}

The sample for study 2 consisted of 201 fans gathered after the 36th round of the 2013 Brazilian Championship. We then tried to analyze the attitude of fans towards the club with regard to the celebrity effect (current vs. former) along with the outcome of the match (victory vs. defeat). Participants were asked to read a testimonial from idols in favor of their teams; photos of the idols were used to endorse their images to fans. The idols of each team can be viewed in Appendix A.

\subsubsection{Results}

As in Study 1, we compared the relation of match outcome with the level of happiness of fans. In study 2, the results also confirm this relation. Fans representing teams that had just won $\left(\mathrm{HAP}_{\text {vic }}=7.23\right)$ were happier than those whose team had lost $\left(\operatorname{HAP}_{\mathrm{def}}=3.72 ; \mathrm{F}(1,200)=\right.$ $82,949, \mathrm{p}<.000$ ); we concluded that the happiest consumers are more prone to buy their team products immediately after the positive outcome of a match.

The analysis of variance showed a non-significant interaction between idol and match outcome $(\mathrm{F}(1.200)=0.260, \mathrm{p}=.610)$. The fans, both in victory and in defeat, have not had their attitude changed significantly by the idol $(\mathrm{F}(1.200)=.169, \mathrm{p}=.601)$. But the outcome of the match (victory vs. defeat), representing the concept of happiness, showed a significant index in the attitude of fans $(\mathrm{F}(1.200)=2.892, \mathrm{p}=.091)$, confirming once again our analysis relating the outcome of the match to happiness. 


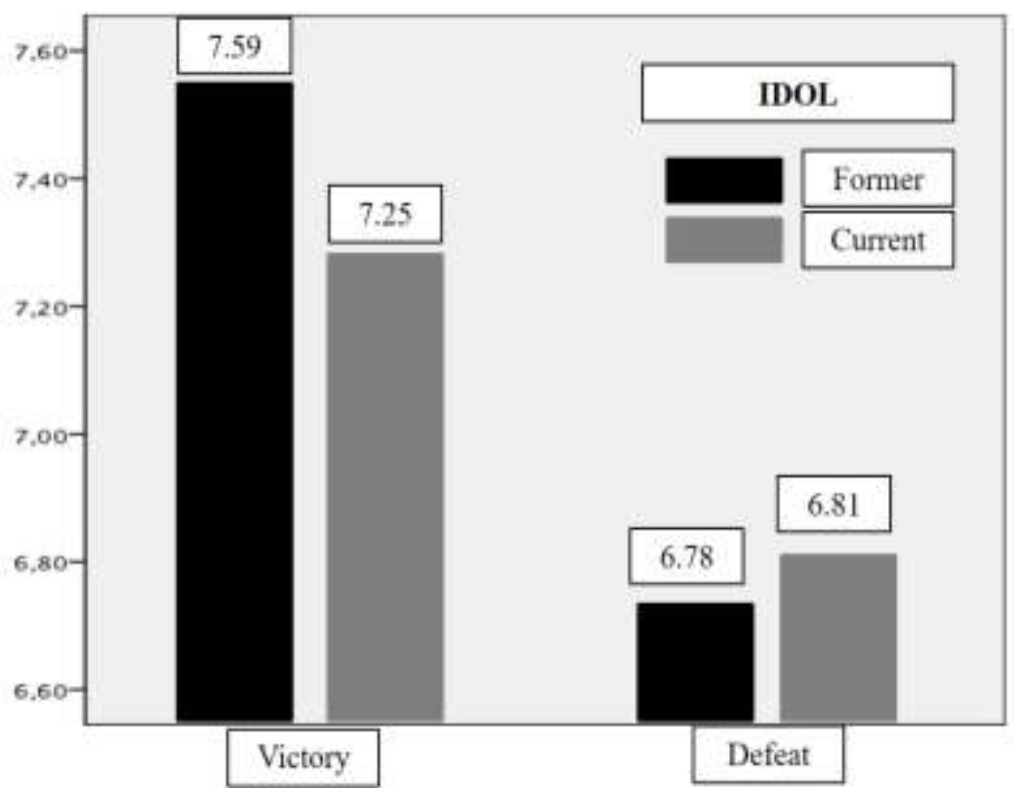

Figure 3 - Effect of the idol as a pitchman and the outcome of the match on the attitude of fans

Source: Survey data.

The analysis shows that both former and current idols do not significantly impact on the attitude of fans - in other words, the hypothesis is once again not confirmed. It was evident that, as in study 1, happiness causes more impact on the attitude of fans than the choice of pitchman (celebrity or idol) when stimulated immediately after the end of a match.

On the other hand, when comparing the averages of study 1 (celebrities) with the averages of study 2 (idols), we noted that in the second study the values are higher in all situations, and idols are more impactful than celebrities considering the stronger bond they have due to the history built in the club and more affective relationship with fans (MORATO et al., 2011). This result helps us understand, as pointed out by Carlson and Donavan (2008), the reason behind the greater use of product endorsing specialist-celebrities. Moreover, the construction of an idol goes beyond a celebrity figure (HELAL, 2003), confirming the literature reviewed.

Despite the failure to confirm the hypotheses in both studies, the results indicate that regardless of the particular type of pitchman, the happiness provided by the outcome of a game is a stronger influence on the attitude of fans than any marketing stimulus for short term actions. So, for study 3 we decided to analyze the level of fan involvement towards the sport and their teams.

\subsection{STUDY 3 - INVOLVEMENT}

In general, there are three forms of involvement with the sport: behavioral, cognitive and affective (MULIN, 2004). In line with attitude, involvement mixes the rational and 
emotional feelings of people towards a goal (ZHAO et al., 2011). Purchasing decisions are generated from the combination of these sensations. Kunkel et al. (2013) suggest a personal connection with the sport and the team as involvement. An involved fan is one who seeks information about his team, is interested in the backstage, prepares for the game and talks about the results with friends and colleagues the next day, in other words, involved fans demonstrate interest on information about their clubs (KUNKEL et al. 2013).

For Meenaghan (2001), involvement is a dimension that precedes the consumer purchase intent. Shank and Beasley (1998) conclude that people with a high level of involvement with the team spend more time watching sports programs on television and reading about sports, and attend more sporting events than people with low involvement. The authors argue that involvement with the sport is a good indicator to predict sports-related behaviors.

Dees, Bennett and Villegas (2008) state that the higher one's involvement with the sport is, the greater one's intent to purchase products of its sponsors will be. It is in this very sense of high involvement merged with increased happiness, enabled by the outcome of matches, that a positive attitude is expected of fans towards their favorite club, therefore:

H3 Fans with greater involvement have higher attitudes in favor of their team than those with lesser involvement, both in victory and defeat.

\subsubsection{Method}

The sample of study 3 consisted of 265 fans gathered after the 37th round of the 2013 Brazilian Championship. Unlike the first two studies, study 3 had no stimuli manipulation. Given the non-significant results for celebrity and idols of teams with the pitchman, we then tried to analyze the attitude towards the club regarding the level of involvement (high vs. low) and the outcome of the match (victory vs. defeat). The level of involvement (high vs. low) was established by the median of the average of variables of the involvement construct.

\subsubsection{Results}

Although a significant statistic was not found for the interaction between outcome and level of involvement $(\mathrm{F}(1,264)=.477, \mathrm{p}=.490)$, separately, there are significant relationship between the two variables. In the scenario of high involvement, both in defeat and in victory fans with greater involvement had higher attitude towards the club $\left(\mathrm{HI}_{\mathrm{vic}}=8.01 \mathrm{vs} . \mathrm{HI}_{\mathrm{def}}=\right.$ 7.37). In the low involvement scenario, the logic is the same, but with lower averages, as expected $\left(\mathrm{LI}_{\mathrm{vic}}=6.85 \mathrm{vs} . \mathrm{LI}_{\mathrm{def}}=5.89 ; \mathrm{F}(1,264)=33.175, \mathrm{p}<.000\right)$. 


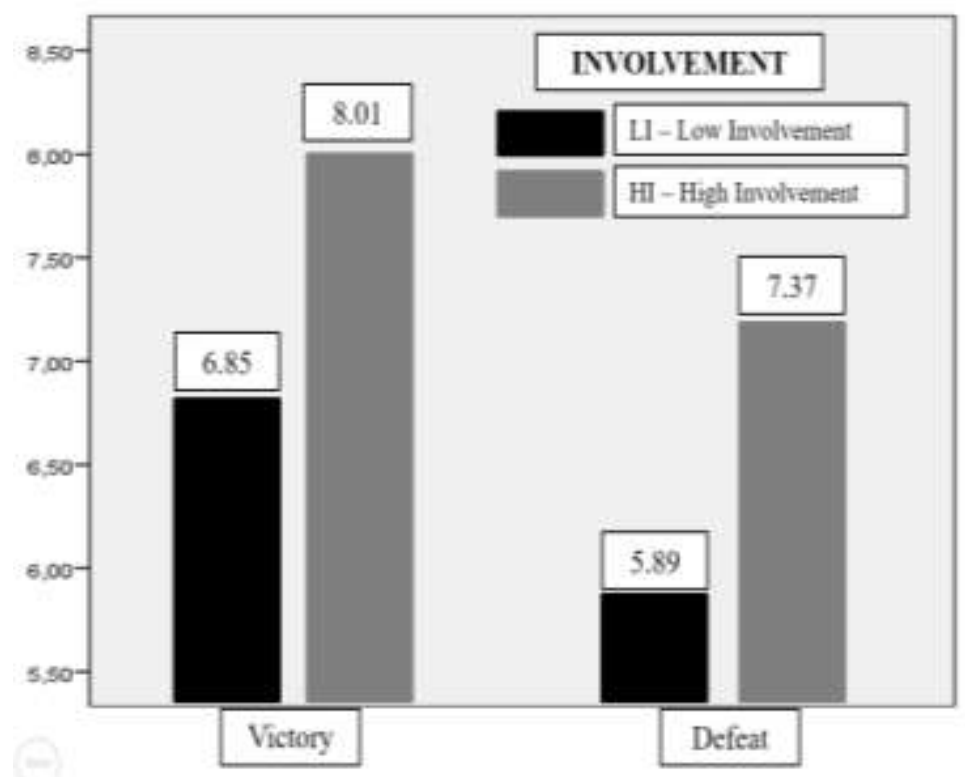

Figure 4 - Effect of involvement and the outcome of the match on the attitude of fans

Source: Survey data.

Thus, we concluded that hypothesis 3 was confirmed - in situations of victory or defeat, consumers who are more involved are those with greater attitude towards their clubs. In this research, consumers with greater involvement are the ones that: go over to the stadium, seek daily information about their teams from different sources, like to talk about their teams and use their products.

This result confirms the theoretical approach presented by Shank and Beasley (1998) and Dees et al. (2008), when they argue that consumers who are more involved are more likely to buy their team products and merchandising than the ones who are not as involved. Moreover, in addition to being more involved, consumers who are happy due to a positive outcome will have their attitude intensified.

The power of involvement is evidenced when even upon defeat, fans with high involvement level present better attitude than fans with low involvement upon victory $\left(\mathrm{HI}_{\mathrm{def}}=\right.$ 7.37 vs. $\mathrm{LI}_{\mathrm{vic}}=6.85$ ), showcasing the strength of this construct for the attitude of fans. More than controlling marketing decisions, such as choice of pitchman, the clubs should also target their fans according to their level of involvement and understand how they behave in different scenarios, as upon game results, "playoffs" or point system tournaments, among other circumstances. Given this finding, on study 4, we evaluated the fans' fanaticism relationship, which is even stronger than involvement. 


\subsection{STUDY 4 - FANATICISM}

The importance of fans for the clubs goes far beyond its size and includes the strength of the bond between the club and the fans (KUNKEL et al., 2013). The stronger this bond, more representative for the club a fan becomes, increasing the potential of buying related products (WANN; BRANSCOMBE, 1993) and watching the club live or on television, thereby increasing the team's revenue.

This bond built between club and supporter goes beyond the involvement between the parties; it involves the Social Identity Theory (TAJFEL; TURNER, 1979), which suggests the direct association of the individual with a group to represent him in order to gain a positive and distinct social identity. This identification is defined by how fans connect with their teams through their life experiences acquired with defeats and victories (GWINNER; SWANSON, 2003).

In this paper we understand fanaticism as a high level of loyalty or allegiance. "In the context of sport teams, allegiance can be characterized as a commitment to a specific team that is persistent, resistant to change, and influences cognitive thoughts and behavior" (FUNK; JAMES, 2006, p.190). This feeling is what we call fanaticism in Brazil and is present in the lives of many soccer fans. The strong bond built between the fanatic and his club results in lasting effects when associated with the loyalty of supporters (KUNKEL et al., 2013). Thus, the happiness resulting from a match, coupled with strong fanaticism, is expected to generate a positive attitude towards one's favorite team, therefore:

H4: Fans with a greater degree of fanaticism show higher attitudes in favor of their team than those with a lesser degree of fanaticism, both in victory and defeat.

\subsubsection{Method}

The sample of study 4 consisted of 251 fans gathered after the 38th round of the 2013 Brazilian Championship. No variables were manipulated in this study either. Just as with involvement, we divided the level of fanaticism of fans according to the intensity (high vs. low), and we also analyzed it against match outcome (victory vs. defeat). The level of fanaticism (high vs. low) was also established by the median of the average of variables of the fanaticism construct. The scale of fanaticism used in study 4 was adapted from Gwinner and Swanson (2003). 


\subsubsection{Results}

The result of the study 4 follows the path of study 3 . The analysis of variance showed a non-significant interaction between fanaticism and match outcome $(\mathrm{F}(1,250)=.021, \mathrm{p}=$ .884). However, separately, there was a significant relationship between the two variables. In the scenario of high fanaticism, both in defeat and in victory, fans with greater fanaticism levels showed higher attitude towards the club $\left(\mathrm{HF}_{\mathrm{vic}}=7.86\right.$ vs. $\left.\mathrm{HF}_{\mathrm{def}}=7.17\right)$. In a low fanaticism scenario, the logic is the same, but with lower averages, as expected $\left(\mathrm{LF}_{\mathrm{vic}}=\right.$ 6.82vs. $\left.\mathrm{LF}_{\mathrm{def}}=6.06 ; \mathrm{F}(1,250)=21.378, \mathrm{p}<.000\right)$.

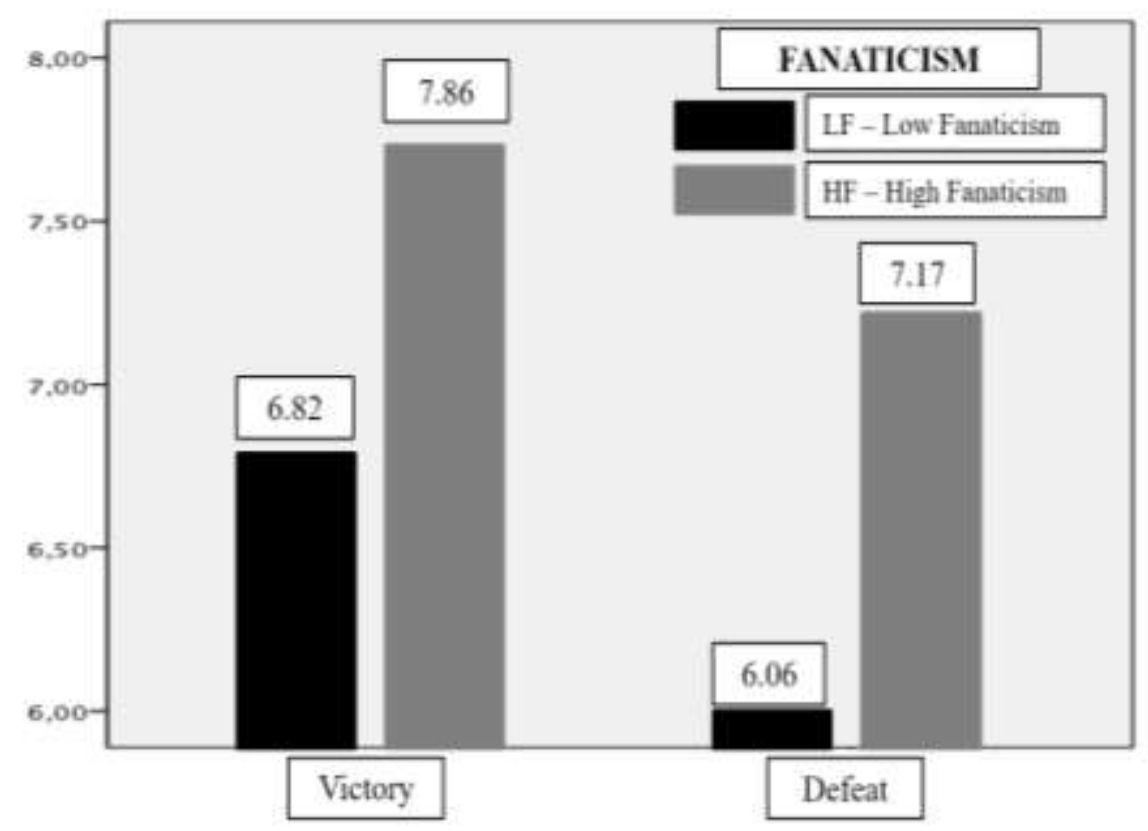

Figure 5 - Effect of fanaticism and outcome of the match on the attitude of fans Source: Survey data.

Social identification theory has mainly been applied to team identification (MADRIGAL, 2001; FINK; TRAIL; ANDERSON, 2002; GWINNER; SWANSON, 2003). Social identity theory proposes that "fans" support those teams that are congruent with their identities (ASHFORTH; MAEL, 1989). Considering the scale adapted from Gwinner and Swanson (2003), in this study, consumers with greater fanaticism are those that: are bothered when their teams are criticized, are interested in what others think about their teams, use the word "we" and not "they" when referring to the athletes as a team, when someone compliments the team, he or she feels complimented as well, and when the press criticizes the team, he feels embarrassed.

Thus, we concluded that hypothesis 4 was confirmed - in situations of victory or defeat, supporters/consumers who are more fanatic for their teams are the ones with greater attitude towards their clubs. The results confirm our literature review reported by Wann and 
Branscombe (1993) and Kunkel et al. (2013) when they state that fanatical supporters show greater attitude towards their clubs. Moreover, when witnessing the victory of their teams, fanatic supporters are happier and intensify the relationship of fans as consumers, that is, they spend more on club-related products and merchandising, thereby increasing their revenues.

The power of fanaticism is evidenced when even upon defeat, highly fanatic supporters show greater attitude than fans with low fanaticism upon victory $\left(\mathrm{HF}_{\mathrm{def}}=7.17 \mathrm{vs} . \mathrm{LF}_{\mathrm{vic}}=\right.$ 6.82), repeating the effect of involvement, showcasing the strength of this construct for the purchase intent of fans. The results of study 4 match the results of study 3 , which indicate the importance of clubs worrying about the profile of their fans far beyond the demographic and regional characteristics, understanding the fans' fanaticism and how they behave in view of a match outcome.

\section{DISCUSSION AND FINAL REMARKS}

The four studies show that, upon high happiness situations, fans tend to have more positive attitudes towards their team than in non-happiness situations. This attitude, as tested in studies 1 and 2 and contrarily to what we expected, remains unchanged when influenced by the use of pitchmen. Thus, despite several studies showing the effectiveness of a pitchman to drive purchase intent and product use, we concluded that at the end of a match, the conative attitude of a fan is not affected by this model of marketing action.

The result of game has a strong power in the supporter. One reason is associated in the bond built between club and supporter that goes beyond the involvement between the parties. When we analyse the result of studies 1 and 2 it's possible identify that individuals are driven by a need for high self-esteem (TAJFEL; TURNER, 1986) and this self-esteem is established, in part, by victory. The team's fans perceive their team as an extension of themselves (WANN; MELNKICK; RUSSELL; PEASE, 2001; FINK; PARKER; BRETT; HIGGINS, 2009).

Moreover, study 3, derived from the negative results found in study 1 and 2, shows that the involvement of fans can result in differentiated attitude towards their clubs when exposed to consumption stimuli immediately after the match. Fans who are more involved, both in defeat (low happiness) and in victory (high happiness), demonstrate greater attitude than fans who are less involved. Study 4 corroborates study 3 by presenting significant changes on the attitude of fans upon the influence of fanaticism. We identified that, both in victory (high happiness) and in defeat (low happiness), fans who are more fanatical show greater attitude towards their clubs. 
This study shows that if there are several factors that make a person more or less happy when it comes to the Brazilian soccer fan, that happiness is a result of the match outcome. Winning on the field may result in immediate victories at the bleachers, as happy fans show more positive attitudes towards their clubs. On the other hand, there is no room for nonhappiness at the bleachers. Fans disappointed with a defeat are not as willing, when it comes to attitudes towards their clubs.

As a managerial contribution, the results of this study point that understanding the level of involvement and fanaticism of fans is crucial for the clubs. In this segment, differentiated marketing actions may be more effective than actions for segments which are already conventionally known, such as income, region, gender and age. Thus, we sought to professionalize the studies and sports management in Brazil, from a both academic and managerial standpoint, in order to minimize mismanagement issues presented in the introduction section, such as debt, arrears of wages and internal and external conflicts in clubs.

As a theoretical contribution, the results show that the endorsement by a celebrity or idol of a club will not always encourage the attitude of fans. The moderating relationship of these two concepts between happiness and attitude proved to be not significant. On the other hand, in view of this result, we analyzed the theoretical concepts of involvement and fanaticism, which in turn prove to be significant moderators in the happiness-attitude ratio. The conclusion is that within the sports environment, emotion is more evident for consumers/fans than in other environments such as food, electronics, automotive, general retail or services, for example, and thus deserves special attention from clubs managers.

\subsection{LIMITATIONS AND FUTURE RESEARCH DIRECTIONS}

This research has some limitations that in turn provide opportunities for future research. First, the study was conducted after point-system championship games; playoff championships may present different results. Moreover, whether the games are at home or not, if the teams are well positioned on the standings or not, and especially the expectation of fans before the game are covariates that may affect attitude after match outcomes.

Several games resulted in a draw in the end. Therefore, many fans have been left out of the final sample in a few rounds. We chose this because the objective of the research is the study of victory and defeat and its relationship with happiness, influencing behavioral conative attitude of fans towards their clubs. Thus, further research studies that examine 
draws and not only victory and defeat are also recommended, as such score is not uncommon in soccer.

Soccer teams, not only in Brazil, compete in various competitions at the same time. This may cause changes in the responses of fans considering the expectation for each game. It is rather common for a team to play with second-string players in the early stages of a minor league. The fact that the research was conducted on the Internet via twitter calls is also a limitation. However, this choice allowed us contact with fans of 16 of the top clubs in the country who are spread throughout Brazil.

Finally, we recommend further research studies to make use of mediating and moderating variables as such as the games are at home or not; the expectation of fans before the game that may affect attitude after match outcomes, or when the fans watch the game. If the fans watch the game by TV or in the Stadium it's possible that the result of the victories or defeats influence will be different when conducting analyzes on the attitude of fans towards their soccer clubs.

\section{CONTRIBUTIONS OF AUTHORS}

Regarding the contribution of each author, we list below the participation by order of the authors :

Fernando A. Fleury developed the purpose of research, participated in the development of the theoretical framework, the construction of the measurement scale in data collection, analysis of results and final considerations .

Vitor Koki da Costa Nogami participated in the development of the theoretical framework, the construction of the measurement scale, analysis of results and final considerations .

José Afonso Mazzon has helped in the analysis of results and collaborated with the guidance of the work and the development of the project .

Andres Rodriguez Veloso has helped in the final considerations and collaborated with the guidance of the work and the development of the project .

\section{REFERENCES}

AJZEN, I.; FISHBEIN, M. Attitude-behavior relations: a theoretical analysis and review of empirical research. Psychological Bulletin, v. 84, n. 5, p. 888-918, 1977.

AJZEN, I. Nature and operation of attitudes. Annual Review of Psychology, v. 52, n.1, p. 27$58,2001$. 
ASHFORTH, B. E.; MAEL, F. Social identity theory and the organization. Academy of Management Review, v. 14, n. 1, p. 20-39, 1989.

BAGOZZI, R. P. Attitudes, intentions, and behavior: a test of some key hypotheses. Journal of Personality and Social Psychology, v. 41, n. 4, p. 607-627, 1981.

BAGOZZI, R. P. et al. The construct validity of the tripartite classification of attitudes. Journal of Marketing Research (JMR), v. 16, n.1, p. 88-95, 1979

BDO. $6^{\mathbf{0}}$ valor das marcas dos clubes brasileiros finanças dos clubes. São Paulo. 2013. Disponível em:

<http://www.bdobrazil.com.br/pt/PDFs/Estudos_Zipados/ValordasMarcasde2013.pdf>. Acesso em: 20 mar. 2014.

CHEN, A. C. H. et al. Who benefits from multiple brand celebrity endorsements? an experimental investigation. Psychology \& Marketing, v. 30, p. 10, p. 850-860, 2013.

CHOI, S.; RIFON, N. J. Who is the celebrity in advertising? Understanding dimensions of celebrity images. The Journal of Popular Culture, v. 40, n. 2, p. 304-324, 2007.

CIALDINI, R. B. et al. Basking in reflected glory: three (football) field studies. Journal of Personality and Social Psychology, v. 34, n. 3, p. 366-375, 1976.

DRUCKER, S.; CATHCART, R. The mediated sports hero, American heroes in a media age. Cresskill, NJ: Hampton.

DEES, W.; BENNETT, G.; VILLEGAS, J. Measuring the effectiveness of sponsorship of an elite intercollegiate football program. Sport Marketing Quarterly, v. 17, n. 2, p. 79-89, 2008

FINK, J. S.; TRAIL, G. S.; ANDERSON, D. F. An examination of team identification: which motives are most salient to its existence? International Sports Journal, Summer, p. 195207, 2002.

FISHBEIN, M.; MIDDLESTADT, S. Noncognitive effects on attitude formation and change: fact or artifact? Journal of Consumer Psychology, v. 4, n. 2, p. 181-202, 1995.

FLEURY, F. A. et al. The impact of the stadium in the supporter's consumption: how does the frequency at the stadium boosts the demand for the clubs. Future Studies Research Journal: Trends and Strategies, v. 6, n. 2, p. 126-156, 2014.

FRIEDMAN, H. H.; FRIEDMAN, L. Endorser effectiveness by product type. Journal of Advertising Research, v. 19, n. 5, p. 63-71, 1979.

FUNK, D. C.; BEATON, A.; ALEXANDRIS, K. Sport consumer motivation: autonomy and control orientations that regulate fan behaviours. Sport Management Review, v. 15, n. 3, p. 355-367, 2012.

FUNK, D. C.; JAMES, J. The psychological continuum model: a conceptual framework for understanding an individual's psychological connection to sport. Sport Management Review, v. 4, n. 2, p. 119-150, 2001. 
GRAY, K.; WATSON, D. Assessing positive and negative affect via self-report. In: ALLEN, J. B.; COAN, J. A. (Eds.). The handbook of emotion elicitation and assessment. New York: Oxford University Press, p. 171-83, 2007.

GRAY, G. T.; WERT-GRAY, S. Customer retention in sports organization marketing: examining the impact of team identification and satisfaction with team performance. International Journal of Consumer Studies, v. 36, n. 3, p. 275-281, 2012.

GUVEN, C. Reversing the question: does happiness affect consumption and savings behavior?. Journal of Economic Psychology, v. 33, n. 4, p. 701-717, 2012.

GWINNER, K.; SWANSON, S. R. A model of fan identification: antecedents and sponsorship outcomes. Journal of Services Marketing, v. 17, n. 3, p. 275-294, 2003.

HELAL, R. A construção de narrativas de idolatria no futebol brasileiro. Alceu, Rio de Janeiro, v. 4, n. 7, p. 19-36, 2003.

JONES, M. J.; DAVID, W. S. The strategic use of celebrity athlete endorsers in sports illustrated: an historic perspective. Sport Marketing Quarterly, v. 9, n. 2, p. 65-76, 2000.

KWAK, D. H.; KIM, Y. K.; HIRT, E. R. Exploring the role of emotions on sport consumers' behavioral and cognitive responses to marketing stimuli. European Sport Management Quarterly, v. 11, n. 3, p. 225-250, 2011.

KIM, Y. K.; TRAIL, G. Constraints and motivators: a new model to explain sport consumer behavior. Journal of Sport Management, v. 24, n. 2, p. 190-210, 2010.

KUNKEL, T.; HILL, B.; FUNK, D. Brand architecture, drivers of consumer involvement, and brand loyalty with professional sport leagues and teams. Journal of Sport Management, v. 27, n. 3, p. 177-192, 2013.

LABROO, A. A.; PATRICK, V. M. Psychological distancing: why happiness helps you see the big picture. Journal of Consumer Research, v. 35, n. 5, p. 800-809, 2009.

LAYARD, R. Happiness: lessons from a new science. New York: Penguin Press, 2005.

LEMKE, R. J.; LEONARD, M.; TLHOKWANE, K. Estimating attendance at Major League Baseball games for the 2007 season. Journal of Sports Economics, v. 11, n. 3, p. 316-348, 2010.

LEWIS, M.; HAVILAND-JONES, J. M.; BARRET, L. F. Handbook of emotions. 3. ed. New York: The Guilfor Press, 2008.

MADRIGAL, R. Social identity effects in a belief-attitude- intentions hierarchy: implications for corporate sponsorship, Psychology \& Marketing, v. 18, n. 2, p. 145-165, 2001.

MCCRACKEN, G. Who is the celebrity endorser? Cultural foundations of the endorsement process. Journal of Consumer Research, v. 16, n. 3, p. 310-321, 1989.

MEENAGHAN, T. Understanding sponsorship effects. Psychology \& Marketing, v.18, n. 2, p. 95-122, 2001. 
MILLAR, M. G.; MILLAR, K. U. Attitude change as a function of attitude type and argument type. Journal of Personality and Social Psychology, v. 59, n. 2, p. 217-228, 1990.

MOGILNER, C.; AAKER, J.; KAMVAR, S. D. How happiness affects choice. Journal of Consumer Research, v. 39, n. 2, p. 429-443, 2012.

MORATO, M. P.; GIGLIO, S. S.; GOMES, M. S. P. A construção do ídolo no fenômenofutebol. Motriz: Revista de EducaçãoFísica, v. 17, n. 1, p. 1-10, 2011.

PHAM, M. T. Emotion and rationality: a critical review and interpretation of empirical evidence. Reviewof General Psychology, v. 11, n. 2, p. 155-178, 2007.

PLURI. O PIB do esporte brasileiro. 2012. Disponível em:

<http://www.pluriconsultoria.com.br/uploads/relatorios/PIB\%20Esporte.pdf>. Acesso em: 19 fev. 2014.

$1^{\text {a }}$ pesquisa Pluri \& Stochos: tamanho das torcidas. 2013. Disponível em:

<http://www.pluriconsultoria.com.br/uploads/relatorios/PLURISTOCHOS\%20Pesquisa\%20r egiao\%20nordeste.pdf>. Acesso em: 19 fev. 2014.

QUICK, S. Contemporary sport consumers: some implications of linking fan typology with key spectator variables. Sport Marketing Quarterly, v. 9, n. 3, p. 149-156, 2000.

SHANK, M. D.; BEASLEY, F. M. Fan or fanatic: refining a measure of sports involvement. Journal of Sport Behavior, v. 21, n. 4, p. 435-443, 1998

SILVERA, D. H.; AUSTAD, B. Factors predicting the effectiveness of celebrity endorsement advertisements. European Journal of marketing, v. 38, n. 11/12, p. 1509-1526, 2004.

SHIMP, T.A. Advertising promotion: supplemental aspects of integrated marketing communications. 5. ed. Fort Worth, TX: Dryden Press, 2000.

SHUART, J. Heroes in sport: assessing celebrity endorser effectiveness, International Journal Of Sports Marketing \& Sponsorship, v. 8, n. 2, p. 126140, 2007.

STERNTHAL, B.; PHILLIPS, L. W.; DHOLAKIA, R. The persuasive effect of scarce credibility: a situational analysis. Public Opinion Quarterly, v. 42, n. 3, p. 285-314, 1978.

TAJFEL, H.; TURNER, J. C. An integrative theory of intergroup conflict. The Social Psychology of Intergroup Relations, v. 33, n. 47, p. 74-91, 1979.

TAYLOR, R. Football and its fans: supporters and their relations with the game, 1885-1985. Leicester: University Press, 1992.

TOKUYAMA, S.; GREENWELL, T. C. Examining similarities and differences in consumer motivation for playing and watching soccer. Sport Marketing Quarterly, v. 20, n. 3, p. 148$156,2011$.

WANN, D. L.; BRANSCOMBE, N. R. Sports fans: measuring degree of identification with their team. International Journal of Sport Psychology, v. 24, n. 1, p. 1-17, 1993. 
ZHAO, M.; HOEFFLER, S.; ZAUBERMAN, G. Mental simulation and product evaluation: the affective and cognitive dimensions of process versus outcome simulation. Journal of Marketing Research, v. 48, n. 5, p. 827-839, 2011.

\section{APPENDIX A}

\begin{tabular}{|l|l|l|l|l|}
\hline \multicolumn{1}{|c|}{ Team } & \multicolumn{1}{c|}{$\begin{array}{c}\text { Supporter } \\
\text { Celebrity }\end{array}$} & \multicolumn{1}{c|}{$\begin{array}{c}\text { Neutral } \\
\text { Celebrity }\end{array}$} & \multicolumn{1}{c|}{$\begin{array}{c}\text { Idol } \\
\text { Current }\end{array}$} & \multicolumn{1}{c|}{$\begin{array}{c}\text { Idol } \\
\text { Former }\end{array}$} \\
\hline Atlético-MG & Chico Pinheiro & Gisele Bundchen & Diego Tardelli & Reinaldo \\
\hline Atlético-PR & Emanuel & Gisele Bundchen & Paulo Baier & Washington \\
\hline Botafogo & Claudia Leite & Gisele Bundchen & Seedorf & Túlio "Maravilha" \\
\hline Bahia & Zeca Pagodinho & Gisele Bundchen & Fernandão & Bobô \\
\hline Corinthians & Sergio Groissman & Gisele Bundchen & Paulinho & Sócrates \\
\hline Coritiba & Guta Stresser & Gisele Bundchen & Alex & Dirceu Kruger \\
\hline Cruzeiro & Samuel Rosa & Gisele Bundchen & Fábio & Sorín \\
\hline Flamengo & Jorge Ben & Gisele Bundchen & Léo Moura & Zico \\
\hline Fluminense & Pedro Bial & Gisele Bundchen & Fred & Edinho \\
\hline Grêmio & Fernando Lima & Gisele Bundchen & Kleber & Renato Gaúcho \\
\hline Internacional & Renata Fan & Gisele Bundchen & D'Alessandro & Falcão \\
\hline Palmeiras & Mauro Betting & Gisele Bundchen & Valdivia & Marcos \\
\hline Santos & Chorão & Gisele Bundchen & Neymar & Pelé \\
\hline São Paulo & Henri Castelli & Gisele Bundchen & Rogério Ceni & Raí \\
\hline Vasco da Gama & Marcos Palmeira & Gisele Bundchen & Juninho Pernamb. & Romário \\
\hline Vitória & Ivete Sangalo & Gisele Bundchen & Escudeiro & Ramon Menezes \\
\hline
\end{tabular}

Table 1 - Celebrities and idols by team

Source: Survey data. 


\section{APPENDIX B}

Table 2 - Exploratory Factor Analysis

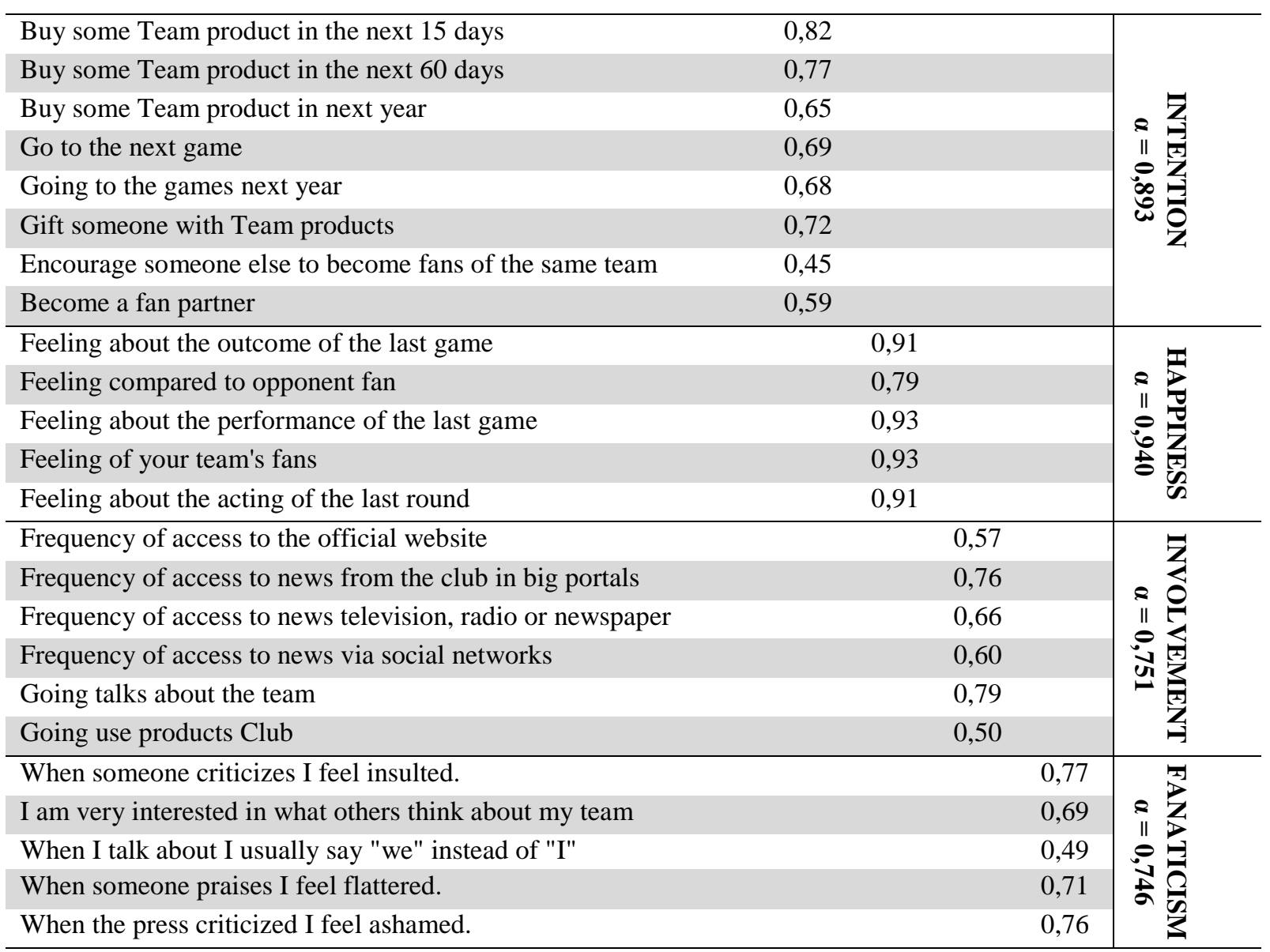

a. Varimax Rotation

b. $\mathrm{KMO}=0,905$ 